\title{
UNIÕES ENTRE PESSOAS DO MESMO SEXO
}

\author{
Álvaro Villaça Azevedo \\ Ex-Diretor da Faculdade de Direito da Universidade de São Paulo e \\ da Faculdade de Direito Mackenzie; Professor Titular de Direito Civil \\ e Direito Romano da Universidade de São Paulo e Mackenzie
}

Resumo:

Nossa sociedade assiste, presentemente, ao fenômeno da convivência, sob o mesmo teto, ou-não, de pessoas do mesmo sexo, por tempo duradouro. Essa união não se assemelha ao casamento civil, como regulado pelo Código Civil, cujo sistema acolhe a diversidade de sexo, como seu pressuposto existencial. É certo que o casamento de homossexuais é admitido em alguns países europeus, como a Dinamarca, Noruega e Suécia. Na Holanda foram criados mecanismos para possibilitar registros dessas uniões, como acontecera na cidade norte-americana de São Francisco. Do mesmo modo, ainda que se cogite de mera convivência, no plano fático, entre as pessoas do mesmo sexo, não se configura a união estável, que é a convivência duradoura de um homem e de uma mulher, como se casados fossem, com o intuito de constituição de família. Existe, entre nós, o Projeto da deputada Marta Suplicy, n. 1.151/95, que objetiva disciplinar a "união civil entre pessoas do mesmo sexo", que é analisado neste trabalho. Essa união, por esse projeto, constituir-se-á mediante registro de escritura pública, em Cartório do Registro Civil. Esse mesmo projeto faz nascer dessa "parceria registrada" estado civil dos conviventes, o que não-existe sequer na união estável. Os parceiros poderão somar suas economias, para possibilitar, com esse somatório, a aquisição de seus bens, especialmente de sua moradia, garantida como bem de família. Também o plano de saúde e seguro de grupo, feito por um, beneficiará o outro. Há restrições, como, por exemplo, a impossibilidade de adoção de filho, pelo casal de parceiros.

\footnotetext{
Abstract:

Our society watches, at present, the partnership phenomenon, between people of the same sex, living together or not, for a long period of time. This "union" has no similarity to the "civil marriage", ruled by the Civil Code, which systematic indicates the heterosexuality as an essential conjecture. It is true that the homosexual marriage is admitted in some European countries, like Denmark, Norway and Sweden. In Netherlands, some mechanisms were developed to make the registration of those unions possible, what had already occurred in San Francisco, United States of America. In the same way, if we think about a simple partnership of two persons of the same sex, it can not configure what we call "stable union" "concubinage", that is represented when a man and a woman live together, as husband and wife, concerned with family constitution, without being legally
} 
married. Among us, there is a law Project, n. $1.151 / 95$, created by a state deputy, Mrs. Marta Suplicy, that aims the regulation of the partnership between people of the same sex, that is analyzed, in this piece of work. This partnership, according to the mentioned project, will be established with its registration (tittle-deed), at the "Civil Register Office" This project creates a discriminated "civil status", what, curiously, does not happen to the concubinage. The partners are able to sum their economies to the acquisition of their properties, specially of their home, that is guaranteed as a homestead. The health plan and the blanket insurance, contracted by one of the partners will benefit the other. There are some restrictions, for example, adoption, which will not be authorized to both of registered partners.

Unitermos: casamento inexistente; união estável inexistente; Projeto Marta Suplicy.

\section{Sumário:}

1. Casamento inexistente. 2. Parceria registrada na legislação estrangeira. 3. União estável inexistente. 4. Análise do Projeto Marta Suplicy e de seu Substitutivo, na Câmara dos Deputados.

\section{Casamento inexistente}

Nossa sociedade assiste, presentemente, ao fenômeno da convivência, sob o mesmo teto, ou-não, de pessoas do mesmo sexo, por tempo duradouro.

Nem se cogite, nessa hipótese, de que se pudesse falar em casamento, como regulado pelo Código Civil, ainda que, por qualquer erro ou inadvertência, venha o ato da união a registrar-se no Cartório. Isto porque, pelo mesmo Código, o casamento, embora sem qualquer determinação expressa de que se realize entre homem e mulher, de acordo com suas rigorosas exigências, não pode prescindir de tal circunstância, indispensável à sua própria existência.

Todo o sistema regulador do casamento civil acolhe a diversidade de sexo como seu pressuposto existencial.

Esse posicionamento decorre, principalmente, da expressa menção, no Código Civil, aos direitos e deveres do marido (arts. 233 a 239) e da mulher (arts. 240 a 255), sendo estes, portanto, os sujeitos da relação jurídica matrimonial. A todo momento, nesse Estatuto Civil, existem referências a cônjuges ou a marido e mulher.

Importante decisão, do Tribunal de Justiça do Estado de Minas Gerais, por sua $1^{\text {a }}$ Câmara, unanimemente, em 16 de novembro de 1982, sendo relator o 
desembargador Paulo Tinoco, ${ }^{1}$ deve ser lembrada, neste passo, segundo a qual "é ato inexistente o casamento de duas pessoas do sexo feminino" e não nulo. Admite esse decisório que deve existir a declaração de inexistência do casamento, pois existiu o ato, não o casamento, daí porque "o ato é nulo"; considerando ato "a realização, formalidade e registro feito nos livros cartorários" A seu turno, roborou o desembargador Oliveira Leite, em seu voto, que a sentença contém impropriedade, principalmente porque declarou nulo casamento inexistente.

Correta, ao nosso ver, a posição acolhida nesse acórdão, porque o pressuposto da diversidade de sexo no casamento não é defeito, sanável ou insanável, desse contrato solene matrimonial, mas requisito essencial de sua própria existência.

Daí poder o juiz declarar a inexistência do casamento, independentemente de ação tendente a esse reconhecimento. Assim julgou a $6^{\mathrm{a}}$ Câmara do Tribunal de Justiça do Estado de São Paulo, sendo relator o desembargador Roque Komatsu, ${ }^{2}$ em 21 de agosto de 1986. Assenta-se, nessa decisão, que "inexistente é o casamento levado a efeito por pessoas do mesmo sexo, tendo sido utilizado falso registro de nascimento para a consumação do ato"

É certo, desse modo, que o ato inexistente nem chega a ingressar no mundo jurídico; todavia, ernbora ele exista no plano fático, às vezes se torna necessário o ajuizamento de ação para desconstituir seus efeitos ou para impedir a produção destes, em decorrência dessa situação de fato, de mera aparência.

2. Parceria registrada na legislação estrangeira

Como vem sendo informado amplamente, muitos países já admitem o casamento entre pessoas do mesmo sexo. ${ }^{3}$

\section{RT $572 / 189$.}

2. RT $615 / 47$.

3. Le Contrat d'Union Civile et Sociale, Rapport de législation comparée, Divisão de estudos de legislação comparada do Serviço dos Negócios europeus do Senado Francês, Senat, outubro de 1997, com 16 páginas; Tereza Rodrigues Vieira, $\mathrm{O}$ casamento entre pessoas do mesmo sexo, no Direito Brasileiro e no Direito Comparado, in Repertório IOB de Jurisprudência, julho de 1996, n. 14/96, 3/12240, pp. 255 e 250, especialmente p. 252; Federico R. Aznar Gil, Las uniones homosexuales ante la legislación eclesiástica, especialmente item 2.b - Legislación europea, in Revista Española de Derecho Canonico, da Universidad Pontificia de Salamanca, janeiro a junho de 1995, n. 138, v. 52, pp. 157 a 190; publicações de revistas e de jornais, em geral. 
Informa Federico R. Aznar Gil ${ }^{4}$ que alguns países europeus, como a Dinamarca, Noruega e Suécia, já aprovaram leis que equipararam, praticamente, as uniões homossexuais ao casamento heterossexual, com algumas restrições, como é o caso da proibição das adoções.

$\mathrm{Na}$ Dinamarca, desde 1984, essa matéria vem sendo estudada por comissões, e, a partir de 1986, foram concedidos alguns direitos patrimoniais às uniões civis homossexuais, que foram legalizadas, em 1989, reconhecendo-se, assim, os "casamentos entre pessoas do mesmo sexo"

A Lei dinamarquesa n. 372, de $1^{\circ}$ de junho de 1989 , da parceria homossexual registrada, que teve início de vigência em $1^{\circ}$ de outubro do mesmo ano, prescreve, em seu item 1, que "duas pessoas do mesmo sexo podem ter sua parceria registrada" Cuidando desse registro, no item 2, estabelece que "a parte $I$, seções 12 e 13 (1) e cláusula l da seção 13 (2) da Lei sobre Formação e Dissolução de Casamento devem ser aplicadas, igualmente, para o registro de parceiros" que só será possível, se ambos ou um dos parceiros tiverem residência permanente na Dinamarca e nacionalidade dinamarquesa.

Essa lei foi de iniciativa do Parlamento dinamarquês, que colocou a Dinamarca como o primeiro país a adotar essa espécie de legislação.

Esclareça-se que a mesma lei, em seu item 2 (3), deixou o procedimento desse registro a ser regulamentado pelo Ministério da Justiça o que, parece, não ocorreu até o presente.

Quanto aos efeitos legais desse registro, assenta-se, em destaque, que a parceria registrada deve produzir os mesmos efeitos legais que o contrato de casamento, devendo ser aplicadas aos parceiros as mesmas disposições que se aplicam aos esposos, com exceção da Lei de Adoção, que não se aplica aos parceiros; também não se aplica a estes a cláusula 3 da seção 13 e 15 da Lei de Incapacidade e Guarda; bem como as disposições de outras leis dinamarquesas que se refiram a um dos cônjuges e de tratados internacionais, a não ser que concordem os outros países participantes.

Quanto à dissolução da parceria, aplicam-se similarmente as partes, ali indicadas, da Lei de Formação e Dissolução do Casamento e da Lei de Administração da Justiça.

4. Ob. cit., p. 161. 
A Lei de Formação e Dissolução do Casamento, a Lei de Herança, o Código Penal e a Lei de Tributos Hereditários foram emendadas, com a introdução da parceria registrada pela Lei n. 373, de $1^{\circ}$ de junho de 1989 , com início de vigência em $1^{\circ}$ de outubro de 1989.

Destaque-se, neste passo, a emenda às Seções 9 e 10 da citada Lei do Casamento. Na Seção 9, para constar que "uma pessoa que tenha contratado, anteriormente, casamento ou que participe de uma parceria registrada, não pode contrair casamento enquanto o casamento ou a parceria anterior existir" Na Seção 10, cuida-se de questão patrimonial, que proíbe a contratação de casamento por quem tenha sido casado ou parceiro, antes da divisão, ou do início dela, perante a Corte, da propriedade conjunta. Só não se aplica tal disposição se os interessados se uniram sob regime da separação total de bens ou quando uma isenção de divisão for concedida, em casos especiais, pelo ministro da Justiça.

Preceito semelhante é o da Lei de Herança, que determina a divisão dos bens comuns antes de novo casamento ou registro de parceria (item 2).

No tocante ao Código Penal dinamarquês, emendou-se sua Seção 208, para constar como crime a contratação de parceria registrada por quem já for casado ou parceiro (prisão até três anos), dentre outras especificações com alterações de penalidades.

A Noruega acompanhou a Dinamarca, aderindo a essa situação em 1993, quase em situação idêntica, pela Lei n. 40, de 30 de abril, que teve início de vigência em $1^{\circ}$ de outubro desse mesmo ano. A lei norueguesa, entretanto, permite que os parceiros possam partilhar da "autoridade parental" (poder familiar ou pátrio poder), o que a lei dinamarquesa proíbe.

O Parlamento sueco, a seu turno, reconheceu o "partenariat" desde $1^{\circ}$ de janeiro de 1995, quando teve início de vigência a Lei de 23 de junho de 1994, oficializando as uniões entre o mesmo sexo. A autora da Lei de Parceria, na Suécia, foi Barbro Westerholm. Todavia, em 1995, já estavam oficializadas quase mil uniões. Destaque-se, entretanto, que o Consulado da Suécia, em Paris, não está autorizando uniões homossexuais. Registre-se, entretanto que, na França, em 1993, concedeu-se a homossexual o direito de se beneficiar do seguro social de seu parceiro.

Essa lei sueca baseou-se em trabalhos da comissão parlamentar, constituída em 1991, contendo quase os mesmos dispositivos da lei dinamarquesa; entretanto, a lei sueca possibilita, facultativamente, a intervenção do juiz para o 
registro da união, mas exige, obrigatoriamente, essa intervenção em caso de ruptura da mesma união.

É de se mencionar que, dos países escandinavos, só a Finlândia não aderiu à legislação da união registrada de pessoas do mesmo sexo. Houve um projeto de lei, junto ao Parlamento finlandês, em maio de 1996, que foi rejeitado em setembro de 1997.

$\mathrm{Na}$ Holanda, em 1991, foram criados registros em alguns municípios, possibilitando que fossem registradas uniões homossexuais, como acontecera em algumas cidades norte-americanas, como São Francisco, ${ }^{5}$ sendo certo que, em 16 de abril de 1996, elaborou-se projeto de uniões entre o mesmo sexo, com $70 \%$ da opinião pública a favor.

Dá-nos conta o Centro Feminista de Estudos e Assessoria (CFEMEA) ${ }^{6}$ de que, na Holanda, houve o "casamento" oficial de dois casais de lésbicas, tornando-se, em fevereiro de 1998, "os primeiros casos de casamento civil legal entre parceiros do mesmo sexo" nesse país, cuja lei que permite a união civil entre homossexuais teve início de vigência em $1^{\circ}$ de janeiro de 1998. "Um dos casamentos foi da cantora Sugar Lee Hoper e a companheira dela. A união legal entre gays na Holanda não é exatamente o mesmo que um casamento. Os parceiros não podem adotar crianças, nem as lésbicas podem ser artificialmente inseminadas"

Essa lei encontra suas origens no projeto de lei do ministro da Justiça, adotado pelo Parlamento holandês, em julho de 1997, que permite aos casais homossexuais, que não podem se casar, bem como aos casais heterossexuais, que não querem se casar, registrar sua união.

A lei holandesa, diferentemente das escandinavas, não apresenta qualquer registro obrigatório no tocante à nacionalidade dos parceiros.

Na Islândia, o Parlamento adotou um projeto do Governo, em 4 de junho de 1996, possibilitando a duas pessoas do mesmo sexo registrar sua união, tendo tido a lei início de vigência em 27 desse mesmo mês e ano.

Esśa lei islandesa guarda as mesmas disposições da lei dinamarquesa, possibilitando, também, que os parceiros possam partilhar a "autoridade parental"

5. Federico R. Aznar Gil, ob. cit., pp. 161 e 162.

6. Jornal do Centro Feminista de Estudos e Assessoria - CFEMEA, Brasília, fevereiro/98, Ano VI, n. 61, p. 2. 
Registre-se, neste passo, que, desde 15 de dezembro de 1973, por decisão da American Psychiatric Association e, depois, em outras organizações internacionais, a homossexualidade foi excluída do rol das doenças mentais, também nas publicações da Classificação Internacional de Doenças.

Desde 1991, a Anistia Internacional considera violação dos direitos humanos a proibição da homossexualidade.

\section{União estável inexistente}

Do mesmo modo, ainda que se cogite de mera convivência, no plano fático, entre pessoas do mesmo sexo, não se configura a união estável.

Realmente, desde que foram considerados efeitos ao concubinato, até o advento da Súmula 380 do Supremo Tribunal Federal, sempre a jurisprudência brasileira teve em mira o par andrógino, o homem e a mulher.

Com a Constituição Federal, de 05 de outubro de 1988, ficou bem claro esse posicionamento, de só reconhecer, como entidade familiar, a união estável entre o homem e a mulher, conforme o claríssimo enunciado do $\S 3^{\circ}$ do seu art. 226 .

Tenha-se presente que os casos de uniões homossexuais submetidos ao Poder Judiciário têm sido poucos.

Muito citada foi a decisão do juiz José Bahadian, da $28^{\mathrm{a}}$ Vara Cível da Comarca do Rio de Janeiro, na ação promovida contra o espólio de um pintor e iniciada em 17 de maio de 1988. Nesse processo reconheceu-se direito do companheiro sobrevivo, em razão do falecimento do outro, após dezessete anos de convivência, à metade do patrimônio por eles amealhado. Patenteou-se, então, a existência de sociedade de fato entre os conviventes e de um patrimônio criado por seu esforço comum. Esta a decisão de primeiro grau.

Pondere-se, neste caso, que esse direito à metade do patrimônio do companheiro falecido estava assegurada por testamento deste, assinado em 1985 , revogado por outro testamento, firmado pelo testador quando já estava internado, em estado grave, no Memorial Hospital de Nova York, conforme atestaram algumas testemunhas, e que não estaria o mesmo na plena capacidade de entendimento dos fatos; tudo segundo ampla divulgação, à época, pela mídia.

Em grau de apelação, no Tribunal de Justiça do Estado do Rio de Janeiro, em 08 de agosto de 1989, unanimemente, por sua $5^{\text {a }}$ Câmara Cível, sendo 
relator o desembargador Narcizo A. Teixeira Pinto, ${ }^{7}$ decidiu-se esse caso, como demonstra a ementa oficial: "Açâao objetivando o reconhecimento de sociedade de fato e divisão dos bens em partes iguais. Comprovada a conjugação de esforços para formação do patrimônio que se quer partilhar, reconhece-se a existência de uma sociedade de fato e determina-se a partilha. Isto, porém, não implica, necessariamente, em atribuir ao postulante $50 \%$ dos bens que se encontram em nome do réu. A divisão há de ser proporcional à contribuição de cada um. Assim, se os fatos e circunstâncias da causa evidenciam uma participação societária menor de um dos ex-sócios, deve ser atribuído a ele um percentual condizente com a sua contribuição."

Como visto, nesse julgado, reconheceu-se, tão-somente, a sociedade de fato, entre sócios, e não união livre como entidade familiar. Deixou evidenciado esse acórdão que a mesma Câmara, em outra decisão, em que foi relator o desembargador José Carlos Barbosa Moreira, evidenciou que "'o benefício econômico não se configura apenas quando alguém aufere rendimentos, senão igualmente quando deixa de fazer despesas que, de outra maneira, teria de efetuar' (Apelação Cível 38.956/85). E assim deve ser, porque o esforço comum, que caracteriza a sociedade de fato, pode ser representado por qualquer forma de contribuição: pecuniária ou através da doação de bens materiais ou ainda por meio de prestação de serviços. Este, sem dúvida, o sentido que o Código Civil brasileiro, ao definir o contrato de sociedade, empresta à locução 'combinar esforços ou recursos para lograr fins comuns' (art. 1.363). Como é de primeira evidência, a expressão 'esforços ou recursos' abrange todas as formas ou modalidades de contribuições para um fim comum.

E se conclui nesse mesmo decisório que, "por maior que tenha sido a contribuição do apelado à obra do pintor, não se pode conceber que tenha sido equivalente à que deu o próprio criador dos quadros. E, não tendo sido iguais as cotas de contribuição, não podem ser iguais, como pretende o recorrido, os quinhões na partilha. A participação na divisão deve ser proporcional à contribuição para criação ou aquisição dos bens.

Daí a redução do percentual estabelecido na sentença, de 50\% para $25 \%$ do patrimônio adquirido pelo esforço comum.

7. Jurisprudência Brasileira Cível e Comercial, Ed. Juruá, Curitiba, União Livre, 1994, n. 173, pp. 206 a 209. 
Também o Tribunal de Justiça do Estado de Minas Gerais, por sua $2^{\mathrm{a}}$ Câmara, em 3 de dezembro de 1996, sendo relator o juiz Carreira Machado, ${ }^{8}$ decidiu que "a união de duas pessoas do mesmo sexo, por si só, não gera direito algum para qualquer delas, independentemente do periodo de coabitação"

Nesse caso, ainda, foi negada indenização por dano moral, reivindicado pelo companheiro sobrevivo, junto ao pai do falecido, vítima de Aids, malgrado tivesse esse sobrevivente "assumido assistência ao doente, expondo-se publicamente, em face da omissão" desse genitor, "a quem não pode ser atribuída culpa pela enfermidade" contraída por seu filho.

Lembra, a seu turno, Rainer Czajkowski ${ }^{9}$ que existe, em torno do tema, uniões homossexuais, "uma forte carga negativa, de ordem moral e mesmo religiosa na sua avaliação"; desta maneira, para que isso seja evitado, "na medida em que o relacionamento íntimo entre duas pessoas do mesmo sexo pode ter efeitos jurídicos relevantes, é mais razoável que se faça uma abordagem jurídica e técnica da questão, e não uma análise moral, porque esta última, além de ser excessivamente subjetiva, concluirá pela negativa de qualquer efeito útil"

Pondere-se, neste ponto, que, provada a sociedade de fato entre os conviventes do mesmo sexo, com aquisição de bens pelo esforço comum dos sócios, está presente o contrato de sociedade, reconhecido pelo art. 1.363 do Código Civil, independentemente de casamento ou de união estável. Sim, porque celebram contrato de sociedade as pessoas que se obrigam, mutuamente, a combinar seus esforços pessoais e/ou recursos materiais, para a obtenção de fins comuns.

Registre-se, neste ponto, a celeuma em torno de uma decisão unânime do Superior Tribunal de Justiça, de sua $4^{\text {a }}$ Turma, sendo relator o ministro Ruy Rosado de Aguiar, ${ }^{10}$ que, na verdade, não atribuiu direito de herança a homossexual, mas reconheceu direito à partilha de bens adquiridos, pelos parceiros, em decorrência de sua colaboração comum.

Do mesmo modo, foi normal a decisão unânime da Câmara Especial do Tribunal de Justiça do Estado de São Paulo, sendo relator o desembargador

8. RT 742/393.

9. Reflexos Jurídicos das Uniões Homossexuais, in Jurisprudência Brasileira, Ed. Juruá, 1995, Separação e Divórcio II, v. 176, pp. 95 a 107, especialmente p. 107.

10. Euclides Benedito de Oliveira, Direito de herança entre homossexuais causa equívoco, artigo, in Tribuna do Direito (jornal), abril de 1998, p.12. 
Dirceu de Mello, ${ }^{11}$ de 31.07.97, quando se entendeu deferir a guarda de criança a homossexual, constatando-se que essa circunstância, naquele momento, não era obstáculo à medida, dada a provisoriedade da natureza da guarda, que pode ser revogada a qualquer momento, ante qualquer desvirtuamento na formação psicológica da criança. Entendeu-se que era dificultoso, à época, colocar a criança sob cuidados de uma família-substituta.

Enquanto a união homossexual não for reconhecida como apta à constituição de família, o que nos parece prematuro, os parceiros devem acautelar-se com realização de contratos escritos, que esclareçam a respeito de seu patrimônio, principalmente demonstrando os bens que existem, ou venham a existir, em regime de condomínio, com os percentuais estabelecidos ou-não. Se for o caso, para que não esbarrem suas convenções no direito sucessório de seus herdeiros, devem realizar testamentos esclarecedores de suas verdadeiras intenções. Podem, ainda, os parceiros adquirir bens em nome de ambos, o que importa condomínio, em partes iguais.

4. Análise do Projeto Marta Suplicy e de seu Substitutivo na Câmara dos Deputados

A deputada federal Marta Suplicy apresentou o Projeto de Lei n. 1.151, de 1995, que objetiva disciplinar a "união civil entre pessoas do mesmo sexo"

Como bem pondera a autora desse projeto, ${ }^{12}$ não se pode mais negar a existência de relações homossexuais e as diferentes formas de expressão da sexualidade, no Brasil e em outros países, sendo necessário "garantir direitos de cidadania sem discriminar as pessoas devido à sua orientação sexual".

E continua dizendo que seu projeto "não se refere ao casamento, nem propõe a adoção de crianças ou a constituição de família. Simplesmente possibilita às pessoas homossexuais que vivem juntas o direito à herança, previdência, declaração comum de imposto de renda e nacionalidade. Basicamente, direitos jurídicos para pessoas que pagam impostos e hoje são ignoradas pela sociedade. A

11. JTJ-Lex 198/121.

12. O sol e a peneira, última página da Revista Manchete, Ed. Bloch, Rio de Janeiro, 06 de julho de 1996, p. 98. 
sociedade nos educa para a heterossexualidade como sendo esta a única forma correta e aceita de viver a sexualidade.

Instalou-se uma Comissão Especial na Câmara dos Deputados para apreciar esse projeto, presidida pela deputada Maria Elvira, tendo como relator o deputado Roberto Jefferson.

Prestando depoimento junto a essa Comissão, Luiz Edson Fachin sugeriu a substituição do termo "união" por outro mais adequado. O relator dessa Comissão entendeu correta essa sugestão, substituindo a palavra "união" por "parceria"

Esse jurista paranaense, ${ }^{13}$ escrevendo sobre a convivência de pessoas do mesmo sexo, em outubro de 1996, conclui seu artigo, ponderando que "Humanismo e solidariedade constituem, quando menos, duas ferramentas para compreender esse desafio que bate às portas do terceiro milênio com mais intensidade. Reaprender o significado de projeto de vida em comum é uma tarefa que incumbe a todos, num processo sacudido pelos fatos e pela velocidade das transformações. Em momento algum pode o Direito fechar-se feito fortaleza para repudiar ou discriminar. O medievo jurídico deve sucumbir à visão mais abrangente da realidade, examinando e debatendo os diversos aspectos jurídicos que emergem das parcerias de convívio e de afeto. Esse é um ponto de partida para desatar alguns 'nós' que ignoram os fatos e desconhecem o sentido de refúgio qualificado prioritariamente pelo compromisso sócio-afetivo"

Nessa trilha, passaremos à análise dos artigos do Projeto de Lei n. 1.151, de 1995, da Câmara dos Deputados e de seu Substitutivo, adotado pela Comissão Especial, datado de 10 de dezembro de 1996.

Partiremos dos artigos do aludido Substitutivo, que melhorou a redação do Projeto originário, acrescentando alguns dispositivos de real importância.

Assim, no art. $1^{\circ}$ assegura-se a duas pessoas do mesmo sexo o reconhecimento de sua "parceria civil registrada" objetivando, principalmente, a salvaguarda de seus direitos de propriedade e de sucessão hereditária.

Essa parceria constitui-se mediante registro em livro próprio nos Cartórios de Registro Civil de Pessoas Naturais (art. $2^{\circ}$ ), com a apresentação dos documentos dos interessados enumerados no $\S 1^{\circ}$ : declaração de serem solteiros,

13. Luiz Edson Fachin, Aspectos jurídicos da união de pessoas do mesmo sexo, artigo in $R T$ $732 / 47$ a 54 , especialmente pp. 52 e 53. 
viúvos ou divorciados; prova de capacidade civil absoluta, por meio de certidão de idade ou prova equivalente; e escritura pública de contrato de parceria civil. $O \S 2^{\circ}$ incluído no Substitutivo repete a necessidade de que se registre a parceria, conforme o caput do mesmo artigo. $\mathrm{O} \S 3^{\circ}$ estabelece a impossibilidade de alteração do estado civil dos contraentes, na vigência do contrato de parceria.

Esse $\S 3^{\circ}$ é de extremo rigor, porque corrobora que o pretendido registro, em livro próprio, no Cartório de Registro Civil, mencionado no caput do artigo, não é só para valer contra terceiros, ${ }^{14}$ mas cria, perigosamente, um novo estado civil, que não pode ser alterado sem a extinção do contrato de parceria civil registrada. Esse estado civil nem os conviventes possuem na união estável, que é reconhecida constitucionalmente como forma de constituição de família.

Vê-se, claramente, que, existindo constituição desse estado civil de parceiro ou de parceria, sua desconstituição judicial pode levar muito tempo, sobrecarregando o Poder Judiciário de ações e de processos dessa ordem. Mesmo em caso de morte do parceiro, deverá existir processo judicial para que, seguramente, se constate esse fato, para que possa ser, por decisão do juiz, desconstituído o estado civil, junto ao competente Registro.

Os ônus que se vão criar com isso, e os sérios danos à comunidade, podem ser antevistos; principalmente, se os parceiros se separarem de fato, sem qualquer providência judicial, constituindo novas parcerias de fato.

Entendo a preocupação do pré-legislador em amparar, de certo modo, as parcerias homossexuais; entretanto, essa situação de fato, como é a união estável entre homem e mulher, ficará assoberbada com esses excessos de formalismo, a que o povo brasileiro não está acostumado.

Admito que o registro desses contratos, como defendo a idéia na união estável, é salutar e de alta relevância na salvaguarda de direito de terceiros; todavia, sem que se crie novo estado civil, pois, daí, teremos estado civil de solteiro, de casado, de divorciado e de parceiro civil. Nesse caso, por que não admitir o estado

14. Como constava em nossa Proposta de Regulamentação do concubinato (art. $9^{\circ}$ ); no Projeto de Lei n. 1.888/91 da Câmara do Deputados (art. $4^{\circ}$ ); no Projeto de Lei n. 84/94 (Substitutivo) do Senado Federal (art. $4^{\circ}$ ), ambos baseados em nosso trabalho pré-legislativo, e que redundaram na Lei $n$. 9.278/96, em que foi vetado, pelo presidente da República, o art. $4^{\circ}$, que cuidava do registro para validade contra terceiros; tudo conforme Álvaro Villaça Azevedo, no artigo: Com a Promulgação da Lei n. 9.278, em 10 de maio de 1996, está em vigor o Estatuto dos Concubinos, in Revista Literária de Direito, n. 11, maio/junho de 1996, pp. 14 a 26, especialmente pp. 20, 23 a 26. 
de separado judicialmente (hoje modificação do estado de casamento) e o estado de convivente ou companheiro, em relação à união estável entre homem e mulher?

A criação de estado civil novo cria muitos problemas jurídicos à sua desconstituição, mormente com relação às situações de fato, com regulamentação legal dos efeitos jurídicos da convivência, seja na união estável, seja na parceria civil.

Sugiro, pois, ao legislador que leve em conta estas observações, para admitir o registro do contrato de parceria entre o mesmo sexo, como também propusemos à união estável em nosso projeto, vetado, neste ponto, pelo presidente da República, mas tão-somente para valer contra terceiros. Cria-se, assim, no clima de liberdade da convivência homossexual, como pretende a deputada Marta Suplicy, também um clima de responsabilidade e de Justiça, relativamente a essa união, sem necessidade da criação de um novo estado civil, só alterável com a intervenção do Poder Judiciário.

O registro será feito, então, só para valer contra terceiros. Aliás, nesse ponto, chegamos à conclusão de que o registro mais eficaz é o que se realiza na Circunscrição Imobiliária, onde a averbação das situações jurídicas convivenciais é mais importante, enquanto não houver um cadastramento geral das pessoas que esteja informado em todo o sistema registral. Tudo, para que se evitem alienações de imóveis, por um dos parceiros, em detrimento do outro ou de terceiros, malgrado exista registro do contrato de parceria no Cartório de Registro Civil de Pessoas Naturais.

A seu turno, o art. $3^{\circ}$ do Substitutivo e do Projeto dá caráter solene ao contrato de parceria registrada, o qual deverá ser lavrado em Ofício de Notas, pactuado livremente, mas devendo versar sobre "disposições patrimoniais, deveres, impedimentos e obrigações mútuas".

Se houver disposição expressa no contrato, suas regras podem operar retroativamente para contemplar patrimônio comum, formado anteriormente à união ( $\$ 1^{\circ}$ no Substitutivo; parágrafo único no Projeto).

Inseriu-se no Substitutivo o $\S 2^{\circ}$ desse mesmo art. $3^{\circ}$, pelo qual ficam proibidas disposições sobre adoção, tutela ou guarda de crianças ou de adolescentes, em conjunto, mesmo que sejam filhos de um dos parceiros. Tal providência foi importante para que se evitem traumas de caráter psíquico, principalmente para que não surjam na sociedade filhos ou crianças ou adolescentes que se mostrem só com pais ou só com mães. Sim, porque a autora do Projeto de lei, embora tenha 
manifestado posição contrária à adoção pelos parceiros, a proibição da utilização desse instituto jurídico não se fez, expressamente, em seu texto de pré-legislação.

Anote-se que o Projeto originário previa, nos incisos I e II de seu art. $4^{\circ}$ a extinção desse contrato de parceria pela morte de um dos parceiros ou por decreto judicial. Esta decisão, certamente, ocorrerá em caso de rescisão desse contrato, com descumprimento culposo de qualquer de suas cláusulas ou de dispositivos legais atinentes a essa união, que é a infração contratual, prevista no inciso $\mathrm{I}$, do art. $5^{\circ}$ do Substitutivo e do Projeto, ou, ainda, em caso de denúncia (resilição unilateral), quando a um dos parceiros não mais convier a convivência. Neste último caso, quando houver alegação, por um dos parceiros, de desinteresse na continuidade da união, conforme previsto no inciso II do art. $5^{\circ}$ do Substitutivo e do Projeto.

Nesse ponto, o Substitutivo, mantendo, em seu art. $4^{\circ}$, esses dois incisos do art. $4^{\circ}$ do Projeto, inclui, ainda, um terceiro, para possibilitar, também, essa extinção contratual por consentimento das partes, desde que homologado pelo juiz. Aqui, então, prevista a figura da resilição bilateral ou distrato, em que os parceiros manifestam o desejo de se separarem, perante o juiz, que homologará esse acordo escrito, verificando se foram cumpridos os requisitos legais e contratuais. Aliás, o Projeto já previa, no $\S 1^{\circ}$ de seu art. $5^{\circ}$ a possibilidade de as partes requererem, de comum acordo, consensualmente, a homologação judicial da extinção de sua união civil.

Mesmo incluindo o aludido inciso III, em seu art. $4^{\circ}$, o Substitutivo mantém o mencionado $\S 1^{\circ}$, agora como parágrafo único de seu art. $5^{\circ}$ que, de modo repetitivo, assegura esse requerimento das partes, consensualmente, amigavelmente, pleiteando a homologação judicial da extinção de sua parceria registrada.

Desse modo, atualmente, esse Substitutivo possibilita a referida extinção contratual por morte ou por via judicial, litigiosa ou amigável.

Ocorrendo a mencionada extinção contratual, a sentença, que declarar extinta a parceria, deverá conter a partilha dos bens dos parceiros, nos moldes do contrato dos interessados (art. $6^{\circ}$ do Projeto e do Substitutivo).

Assinale-se que o art. $7^{\circ}$ do Projeto foi eliminado, e exigia a averbação do registro da constituição ou da extinção da união civil, nos assentos de nascimento e de casamento das partes.

$\mathrm{O}$ art. $8^{\circ}$ do Projeto, ainda, instituía como crime de ação pública condicionada à representação "manter o contrato de união civil" referido no aludido 
Projeto, "com mais de uma pessoa, ou infringir o $\S 2^{\circ}$ do art. $2^{o "}$, punível com pena de detenção de seis meses a dois anos.

Essa proibição de parceria civil com mais de uma pessoa, do art. $8^{\circ}$ foi reformulada, no Substitutivo, em seu art. $7^{\circ}$, sendo nulo de pleno direito o contrato que se fizer nesses moldes, ou, ainda, quando houver infração ao $\S 2^{\circ}$ do art. $2^{\circ}$ : do mesmo Substitutivo (falta de registro desse contrato no Registro Civil de Pessoas Naturais).

Estabelece-se, ainda, no parágrafo único desse art. $7^{\circ}$ que a infração mencionada no caput deste implica o cometimento de crime de falsidade ideológica, sujeitando o infrator às penas previstas no art. 299 do Código Penal. ${ }^{15}$

O intuito do pré-legislador foi, em verdade, o de proibir a existência de dois ou mais contratos simultâneos de parceria civil; não, propriamente, o de proibir a existência dessas várias uniões, o que seria impossível.

Desse modo, pode alguém, na prática, ter vários parceiros, o que é impossível de proibir, como acontece com o casamento e o concubinato impuro, ou seja, adulterino ou incestuoso; como pode ocorrer o mesmo com a união estável (concubinato puro) e o concubinato desleal (em concorrência com o primeiro).

Essas situações ocorrem na sociedade independentemente do que queira, ou-não, o legislador. O que este pode coibir é o duplo registro civil.

Por outro lado, para tentar impedir um registro, ante eventual existência de uma parceria civil, com escritura não-registrada, é que o Substitutivo, sob cogitação, instituiu o crime de falsidade ideológica para os parceiros que venham a registrar uma parceria, tendo omitido a existência de parceria ou de registro de escritura anterior. O crime, portanto, consiste nessa omissão e não na manutenção de duas ou mais parcerias.

Tenha-se presente, ainda, que, existindo registro de uma parceria anterior, o próprio Cartório Civil impedirá o registro de outra escritura. O difícil será, eventualmente, acusar registro anterior, se não houver cadastramento do Registro das parcerias.

15. Art. 299 do Código Penal: "Omitir, em documento público ou particular, declaração que dele devia constar, ou nele inserir ou fazer inserir declaração falsa ou diversa da que devia ser escrita, com o fim de prejudicar direito, criar obrigação ou alterar a verdade sobre fato juridicamente relevante: Pena - reclusão, de 01 (um) a 05 (cinco) anos, e multa, se o documento é público, e reclusão de 01 (um) a 03 (três) anos, e multa, se o documento é particular. Parágrafo único: Se o agente é funcionário público, e comete o crime prevalecendo-se do cargo, ou se a falsificaçäo ou alteração é de assentamento de registro civil, aumenta-se a pena de sexta parte." 
No art. $8^{\circ}$ do Substitutivo ( $9^{\circ}$ do Projeto), alteram-se os arts. 29,33 e 167 da Lei n. 6.015, de 31 de dezembro de 1973 (Lei de Registros Públicos).

$\mathrm{O}$ art. 29, onde constam os atos que se fazem registrar no Registro Civil de Pessoas Naturais, fica acrescido do inciso IX, a autorizar, também, o registro dos "contratos de parceria civil registrada entre as pessoas do mesmo sexo" No $\S 1^{\circ}$, desse artigo, que cuida das averbações, fica autorizada a averbação da "sentença que declarar a extinção da parceria civil registrada entre pessoas do mesmo sexo"

No referido art. 33 inclui-se, em seu inciso III, o livro $E$, para "registro de contratos de parceria civil registrada entre pessoas do mesmo sexo"

Finalmente, no art. 167. que menciona as atribuições relativas ao Registro de Imóveis, fica acrescido o item 35 (deverá ser item 36, porque, atualmente, já existe o item 35, que foi inserido pela Lei n. 9.514, de 20 de novembro de 1997), ${ }^{16}$ de seu inciso I, pelo qual, além da matrícula, será feito o registro "dos contratos de parceria civil registrada entre pessoas do mesmo sexo que versem sobre comunicação patrimonial, nos registros referentes a imóveis ou a direitos reais pertencentes a qualquer das partes, inclusive os adquiridos posteriormente à celebração do contrato" Acrescenta-se, ainda, no inciso II, desse art. 167. em seu item 14, a averbação, também, das sentenças de extinção de parceria civil registrada entre pessoas do mesmo sexo ao lado das "sentenças de separação judicial, de divórcio, de nulidade ou anulação do casamento", sempre que, em qualquer delas, "nas respectivas partilhas existirem imóveis ou direitos reais sujeitos a registro".

$\mathrm{O}$ art. $9^{\circ}$ do Substitutivo (art. 10 do Projeto) institui, como bem de família, o imóvel próprio e comum dos contratantes de parceria civil registrada, tornando-o impenhorável, nos moldes da Lei n. 8.009, de 29 de março de 1990.

Essa Lei n. 8.009/90, que regulamenta o bem de família, só considera como tal "o imóvel residencial próprio do casal ou da entidade familiar" Comentando esse dispositivo legal, já ponderei que "um dos requisitos a que se constitua, em bem de família, esse mesmo imóvel é que deva ser de propriedade do casal, ou da entidade familiar. Todavia, nada impede que esse imóvel seja de propriedade de um dos cônjuges, se, por exemplo, não forem casados pelo regime de comunhão de bens. O mesmo pode acontecer com um casal de conviventes, na 
união estável, ou com os integrantes de outra entidade familiar, sendo um só deles proprietário do imóvel residencial, em que vivem. Basta, assim, que um dos integrantes do lar seja proprietário do imóvel residencial, a se constituir em bem de família' 17

Como resta evidente, tal dispositivo de pré-legislação desvirtua a lei analisada, pois na parceria civil registrada não-existe intuito de constituição de família, não-existe lar, o que impede que exista o bem de família. Entretanto, se tal dispositivo vingar, teremos, aí, uma exceção, em completa dissonância com a Lei n. 8.009/90. Sim, porque o bem de família só pode existir no âmbito desta.

A seu turno, os arts. 10 e 11 do Substitutivo simplificam os textos dos arts. 11 e 12 do Projeto.

Assim, o art. 10 inscreve o parceiro como beneficiário do Regime Geral de Previdência Social, como dependente de seu parceiro segurado, desde que esteja registrado o contrato de parceria civil; extinto este, cancela-se, automaticamente, essa inscrição de beneficiário.

Melhor o texto do Substitutivo, porque prescinde da inclusão, nos $\S \S$ $3^{\circ}$ e $2^{\circ}$ respectivamente, dos arts. 16 e 17 da Lei n. 8.213, de 24 de julho de 1991, de matéria relativa à parceria civil, juntamente com a da união estável; também no tocante ao cancelamento dessas união e parceria, com o da inscrição do cônjuge, na situação prevista no mencionado $\S 2^{\circ}$ do art. 17 da citada lei.

Do mesmo modo, no art. 11 do Substitutivo (art. 12 do Projeto), desde que comprovada a parceria civil, o parceiro será considerado beneficiário da pensão prevista no inciso I, do art. 217, da Lei n. 8.112, de 11 de dezembro de 1990, que disciplina o regime jurídico dos servidores públicos civis da União, das autarquias e das fundações públicas federais.

O art. 12 do Substitutivo (art. 13 do Projeto) prevê a necessidade da Administração Pública, estadual, municipal e do Distrito Federal, disciplinar, por legislação própria, os benefícios previdenciários de seus servidores, que tenham relacionamento de parceria civil registrada com pessoa do mesmo sexo.

Por sua vez, o art. 13 do Substitutivo, como o art. 14 do Projeto, concede direitos sucessórios aos contratantes de parceria civil registrada, nos moldes da Lei n. 8.971, de 28 de dezembro de 1994, relativa à união estável. Todavia, o

17. Álvaro Villaça Azevedo, Bem de Familia, Ed. Revista dos Tribunais, São Paulo, $3^{a}$ ed., 1996 , pp. 159 e 160 . 
aludido art. 13, do Substitutivo adapta, em quatro incisos, os casos de sucessão dos conviventes aos dos parceiros.

Assim, o parceiro sobrevivente, desde que não-firme novo contrato de parceria civil registrada, terá direito ao usufruto da quarta parte dos bens de seu parceiro falecido, se este tiver filhos; bem como ao usufruto da metade desses bens se não houver filhos, ainda que sobrevivam os ascendentes do mesmo falecido (incisos I e II). Entretanto, se o parceiro falecido não deixar descendentes e ascendentes, terá o sobrevivente direito à totalidade da herança (inciso III). Ressaltese, neste ponto, que esses três incisos são adaptações dos três primeiros incisos do art. $2^{\circ}$ da Lei n. 8.971 , de 28 de dezembro de 1994, já citada.

Como acontece, presentemente, em matéria de união estável, quanto ao aludido inciso III, se editado este, continuará a existir o absurdo de estarem alijados da herança os colaterais do falecido, relativamente aos bens adquiridos pelo parceiro, morto, antes de construir a parceria civil registrada e os adquiridos, a título gratuito, durante a união.

A seu turno, o inciso IV desse art. 13 do Substitutivo, sob exame, é a adaptação do art. $3^{\circ}$ da atrás mencionada Lei n. 8.971/94 (relativa à união estável). Por ele, se os bens deixados pelo parceiro falecido tiverem resultado de atividade com a colaboração comum do sobrevivente, terá este direito à metade desse patrimônio. Neste passo, está presente a regra de condomínio na aquisição de bens comuns, sem menção de cota condominial; pois, se esta for estipulada em contrato escrito ou no documento, mesmo, de aquisição, deverá ser respeitada.

$\mathrm{O}$ art. 14 do Substitutivo, tratando da matéria cogitada no art. 15 do Projeto, modifica a situação, neste prevista, para pior. Realmente, pois esse art. 14 procura incluir novo inciso no art. 454 do Código Civil, que trata exclusivamente de curatela de cônjuge interdito, não-separado judicialmente; nesse caso, o curador será o outro cônjuge. Na falta deste, os três parágrafos que se seguem escalonam os pais do interdito; na falta destes, o descendente maior, mais próximo, precedendo ao mais remoto; na falta dessas pessoas, o curador escolhido pelo juiz.

Resta evidente que, não sendo a parceria civil registrada considerada casamento entre o mesmo sexo, não há como misturar seu tratamento legislativo com matéria matrimonial. Por isso que, relativamente a essa modificação, melhor será que permaneça indene o art. 15 do Projeto Marta Suplicy, que assenta que, em caso de "perda da capacidade civil" de qualquer um dos parceiros, terá o outro a "preferência para exercer a curatela" 
$\mathrm{O}$ art. 15 do Substitutivo refere-se ao conteúdo do art. 16 do Projeto, objetivando nova redação ao art. 113 da Lei n. 6.815, de 19 de agosto de 1980, que cuida da situação jurídica do estrangeiro no Brasil. Nesse artigo, da apontada Lei, no capítulo que trata das condições da naturalização, menciona-se que o prazo mínimo de residência, para concessão da naturalização, ou seja, quatro anos imediatamente anteriores a esse pedido, fixado no art. 112, inciso III, pode ser reduzido, se o parceiro estrangeiro tiver contrato de parceria civil registrada com pessoa de nacionalidade brasileira. A posição do Projeto é a de incluir a matéria no inciso I do referido art. 113 ("ter filho ou cônjuge brasileiro" e "companheira de união civil entre pessoas do mesmo sexo, brasileiro ou brasileira" Esta redação, além de não ser boa, implica, mais uma vez, a mistura de matéria matrimonial com parceria civil registrada, que não é casamento. Melhor, portanto, a posição do Substitutivo que acrescenta o inciso VI, nesse art. 113, do seguinte teor: "ter contrato de parceria civil registrada com pessoa de nacionalidade brasileira"

O Substitutivo incluiu dois arts., 16 e 17. estes, sim, de grande utilidade e alcance social.

$\mathrm{O}$ art. 16 reconhece aos parceiros o "direito de composição de rendas para aquisição de casa própria" bem como todos os direitos relacionados com "planos de saúde e seguro de grupo"

Como resta evidente, os parceiros podem somar suas economias, para possibilitar, com esse somatório, a aquisição de sua moradia, que ficará garantida, como visto, como bem de família. Também, o plano de saúde e de seguro de grupo, feito por um, beneficiará o outro.

Finalmente, o art. 17 do Substitutivo admite aos parceiros a inscrição, um do outro, como dependentes para efeitos de legislação tributária, já que vivem em sociedade de fato, com ganhos e gastos comuns. Aplicam-se, assim, a eles, as deduções tributárias.

Os dois últimos artigos do Substitutivo, 18 e 19 (arts. 17 e 18 do Projeto), cuidam, respectivamente, do início de vigência, na data em que for publicada a lei, e da revogação de disposições em contrário.

São Paulo, julho de 1998. 